\title{
Retraction Note: 3D printing of surface characterization and finite element analysis improvement of PEEK-HAP-GO in bone implant
}

\author{
Bankole I. Oladapo ${ }^{1} \cdot$ S. Abolfazl Zahedi ${ }^{1} \cdot$ Seng Chong ${ }^{1} \cdot$ Francis T. Omigbodun $^{1} \cdot$ Idowu O. Malachi $^{2}$ \\ Published online: 21 June 2021 \\ (C) Springer-Verlag London Ltd., part of Springer Nature 2021
}

Retracted Note to: The International Journal of Advanced Manufacturing Technology (2020) 106:829-841 https://doi.org/10.1007/s00170-019-04618-w

The Editor-in-Chief has retracted this article due to substantial similarities with a previously published article by different authors [1].

Author Oladapo agrees to this retraction. Authors Zahedi, Chong, Omigbodun and Malachi have not responded to any correspondence from the editor or publisher about this retraction.

\section{Reference}

1. Basgul C, Yu T, MacDonald DW, Siskey R, Marcolongo M, Kurtz SM (2018) Structure-property relationships for 3D-printed PEEK intervertebral lumbar cages produced using fused filament fabrication. J Mater Res 33(14):2040-2051. https://doi.org/10.1557/jmr. 2018.178

Publisher's note Springer Nature remains neutral with regard to jurisdictional claims in published maps and institutional affiliations.

The online version of the original article can be found at https://oi.org/ 10.1007/s00170-019-04618-w

Bankole I. Oladapo

P17243433@my365.dmu.ac.uk

1 School of Engineering and Sustainable Development, De Montfort University, Leicester, UK

2 Department of Mechanical Engineering, Ekiti StateUniversity, Ado-Ekit, Nigeria 